\title{
Microbial diversity in a Pacific Ocean transect from the Arctic to Antarctic circles
}

\author{
Amy J. Baldwin ${ }^{1}$, Joseph A. Moss ${ }^{1}$, Joseph D. Pakulski ${ }^{1}$, Phillipe Catala ${ }^{2}$, \\ Fabien Joux ${ }^{2}$, Wade H. Jeffrey ${ }^{1, *}$ \\ ${ }^{1}$ Center for Environmental Diagnostics and Bioremediation, University of West Florida, Building 58, \\ 11000 University Parkway, Pensacola, Florida 32514 (850) 474-2472, USA \\ ${ }^{2}$ Observatoire Océanologique de Banyuls, Laboratoire d'Océanographie Biologique, Université Pierre et Marie Curie, \\ CNRS UMR7621, BP 44, 66651 Banyuls-sur-Mer Cedex, France
}

\begin{abstract}
Microbial diversity in surface waters was examined along a $15400 \mathrm{~km}$ transect of the Pacific Ocean from $70^{\circ} \mathrm{N}$ to $68^{\circ} \mathrm{S}$ latitude between late August and early November 2003. Comparative microbial diversity was determined using terminal restriction fragment length polymorphism (T-RFLP) analysis of PCR amplified 16S and 18S rDNA restriction digested with CfoI and MspI. Bacterial numbers and total chlorophyll were greatest at higher latitudes in both hemispheres, with a smaller peak in equatorial waters. Flow cytometry analysis indicated a strong peak in Prochlorococcus from approximately $30^{\circ} \mathrm{N}$ to $30^{\circ} \mathrm{S}$. Richness at each station was relatively low, with $\sim 11$ prokaryotic peaks per sample and $\sim 12$ eukaryotic peaks per community. Overall, prokaryotic populations appeared more diverse, with 181 total terminal restriction fragments (T-RFs) generated, while eukaryotic populations produced a total of 135 T-RFs. Prokaryotic and eukaryotic similarity dendrograms revealed 4 distinct cluster groups relating to regions sub-Arctic/Arctic, temperate, tropical and sub-Antarctic/Antarctic. T-RFLP patterns suggest that microbial communities may be influenced by ambient water temperature, with mid-latitudinal and equatorial communities more similar in composition to each other than to cold water communities. Global distribution of prokaryotic communities revealed an average inter-group similarity of $\sim 52 \%$, while eukaryotic communities showed $\sim 51 \%$ similarity, implying that Pacific planktonic communities appear to be fairly homogenous in composition. Several T-RFs were ubiquitously distributed and contributed significantly to each cluster group, while several T-RFs were observed to be endemic to particular oceanic regions. Within-group similarities of $>70 \%$ were attributed to 12-14 T-RFs and 8-11 T-RFs in prokaryotic and eukaryotic profiles, respectively, suggesting that a small number of phylogenetic groups were responsible for each cluster group.
\end{abstract}

KEY WORDS: Microbial diversity $\cdot$ Pacific Ocean $\cdot$ T-RFLP $\cdot$ 16S rDNA $\cdot$ 18S rDNA $\cdot$ Biogeographical distribution

\section{INTRODUCTION}

In order to understand planktonic diversity and the roles of microorganisms in global biogeochemical cycling, we must recognize the distribution patterns of planktonic phylotypes and their controlling environmental factors. The introduction of molecular technologies has revolutionized our view of the microbial world, resulting in a dramatic increase in the number of microbial diversity studies. Before the 1990s, investigations of microbial diversity were driven primarily by culture-based methodologies until Giovannoni et al. (1990) reported the results of a phylogenetically analyzed clone library from the Sargasso Sea. Using 16S rRNA genes, the novel clade SAR11 and the oxygenic phototrophs (cyanobacteria, Synechococcus, Prochlorophytes) were revealed as dominant members of the resident bacterioplankton community (Giovannoni et 
al. 1990). Continual advancement and application of molecular-based technologies has revealed the presence of marine microorganisms that were not detectable by earlier culture based methods (Giovannoni et al. 1990, Fuhrman et al. 1993, DeLong 1998). Molecular methods have revolutionized our understanding of marine microbial communities in terms of the composition, phylogeny, function and physiology within the environment, and they provide further insight into the overall biogeochemical capabilities of microbial communities. These studies contribute greatly to the ever-expanding database of known microbial DNA sequences (Benson et al. 2004), thus aiding further studies of microbial diversity. While commonly used SSU rRNA (small subunit ribosomal RNA) gene 'markers' have limitations, they are an effective means for providing an initial phylogenetic framework from which physiological and ecological impacts can be determined and for garnering an overall view of microbial diversity from single or multiple habitats.

Diversity studies of marine bacterioplankton have revealed that $\sim 80 \%$ of marine bacteria fall within only 9 phylogenetic groups which form clusters of related genes (not single lineages) and appear to be globally distributed (Giovanonni \& Rappé 2000). Of these 9 groups, only 2 have had representatives that have been successfully cultured, indicating the substantial need for molecular-based approaches, especially when examining large-scale distribution patterns of marine bacterioplankton.

In contrast to bacterial phylogenetics using SSU rRNA genes, molecular-based protistan diversity studies have lagged behind due to well-established morphology-based taxonomy. Many protistan groups are of sufficient size to allow for identification based on morphological characteristics alone, although there are concerns about the reliability of morphology for classification purposes (Darling et al. 2000, Norris \& de Vargas 2000). Molecular-based methods enable a more thorough characterization of protistan diversity over a wider range of sampling locations in comparison to culture-dependent techniques and microscopy. These morphology and culture-independent approaches are revealing higher levels of protistan diversity in a variety of ecosystems (Diez et al. 2001, Moon-van der Staay et al. 2001, Gast et al. 2004, Countway et al. 2005).

Most recent microbial diversity studies have been PCR based. Methods such as denaturing gradient gel electrophoresis (DGGE), cloning, sequencing and terminal restriction fragment length polymorphism (TRFLP) allow for the identification of individual species (operational taxonomic units [OTU]) in a heterogenous community based on phylogenetic markers such as
16S rDNA and 18S rDNA (Ward et al. 1990, Diez et al. 2001). T-RFLP is a technique wherein a gene of interest (e.g. 16S or 18S rRNA) is amplified from a heterogenous community using a fluorescently labeled primer. Following digestion with restriction endonucleases, variably sized terminal fragments can be differentiated with high resolution ( \pm 1 base) through use of an automated DNA sequencer allowing researchers to generate 'fingerprints' of complex microbial communities (Liu et al. 1997). This readily applied technique has been shown to be effective in the comparison of microbial assemblages in various marine and terrestrial environments (Urakawa et al. 2001, Mummey \& Stahl 2003, Gomez et al. 2004). Both prokaryotic and eukaryotic diversity have been documented in specific oceanic regions, but not on global scales. Herein we present a T-RFLP-based broad characterization of both the prokaryotic and eukaryotic components of the microbial communities in surface waters collected from the central Pacific Ocean from the Arctic to Antarctic circles during a ship of opportunity cruise: Production Observations Through Another Trans-latitudinal Oceanic Expedition (POTATOE).

\section{MATERIALS AND METHODS}

Sample collection. Samples were collected at 40 stations along a $15400 \mathrm{~km}$ transect of the Pacific Ocean on the RVIB 'Nathaniel B. Palmer' from $70^{\circ} \mathrm{N}$ to $68^{\circ} \mathrm{S}$ latitude between late August and early November 2003 (Fig. 1). Daily surface water samples were collected before sunrise at $\sim 370 \mathrm{~km}$ intervals via bucket casting or Go-Flo bottles (General Oceanics) attached to a CTD rosette. Continuous measurements of surface salinity and temperature along the entire north-south transect were collected by a SeaBird SBE21 underway CTD. Samples for phylogenetic analysis (1 l) were filtered onto $0.2 \mu \mathrm{m} 47 \mathrm{~mm}$ Supor 200 filters (Pall), folded loosely, placed into $2 \mathrm{ml}$ microcentrifuge tubes and stored at $-80^{\circ} \mathrm{C}$ until further processing off ship.

Bacterial production. Bacterial production was measured via the incorporation of ${ }^{3} \mathrm{H}$-leucine (Smith \& Azam 1992). Sample water $(20 \mathrm{ml})$ was amended with ${ }^{3} \mathrm{H}$-leucine (final concentration $10 \mathrm{nM}$ ). Aliquots of $5 \mathrm{ml}$ were placed into 4 WhirlPak bags, one of which contained $0.5 \mathrm{ml}$ of $100 \%$ TCA as a killed control, and incubated for $4 \mathrm{~h}$ in the dark in flowing seawater tables. Incubations were terminated by the addition of TCA to a final concentration of $5 \%$. Samples were processed using the microfuge method of Smith \& Azam (1992).

Chlorophyll a concentration and bacterial cell abundance. Chlorophyll samples were collected in duplicate $500 \mathrm{ml}$ volumes on GF/F filters (Millipore), 


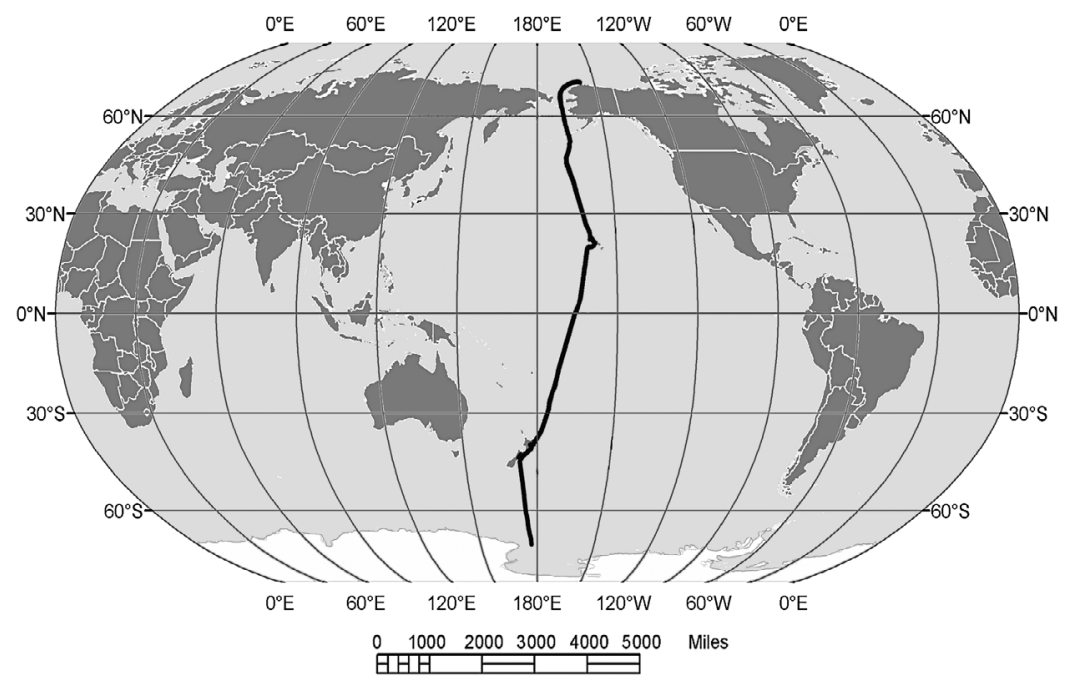

Fig. 1. Transect of sampling sites during the POTATOE cruise, August to November 2003

extracted in $90 \%$ acetone and quantified fluorometrically (Welschmeyer 1994). Bacterial cell concentrations were measured by epifluorescence microscopy of filtered-formalin preserved ( $2 \%$ final concentration, stored at $4^{\circ} \mathrm{C}$ ) DAPI-stained samples (Porter \& Feig 1980).

Nutrient analysis. Samples for inorganic nutrients were collected in $10 \% \mathrm{HCl}$ and sample rinsed polyethylene bottles and frozen $\left(-80^{\circ} \mathrm{C}\right)$ immediately. Nutrient concentrations were measured post-cruise by automated methods (US EEPA 1983).

Flow cytometry analysis of phytoplankton. Samples (3 ml) for flow cytometric analysis of phytoplankton were fixed with $2 \%$ formaldehyde (final concentration) in cryotubes held at room temperature for 10 to $15 \mathrm{~min}$ and then stored at $-80^{\circ} \mathrm{C}$ until analysis. The samples were thawed at room temperature and analyzed on a flow cytometer (FACSCalibur, Becton Dickinson) equipped with a $488 \mathrm{~nm}, 15 \mathrm{~mW}$ Argon laser. Samples were run at $\sim 60 \mu \mathrm{min}^{-1}$ for $5 \mathrm{~min}$. The data were collected, stored and displayed on 4 decade scales using CELLQuest software (Becton Dickinson). Orange fluorescence (from phycoerythrin) was collected through a $585 / 42 \mathrm{~nm}$ filter and red fluorescence (from chlorophyll) through a $650 \mathrm{~nm}$ LP filter. According to their flow cytometric signatures, 4 phytoplanktonic groups were distinguished. Synechococcus cells were easily recognized by their orange fluorescence. Prochlorococcus had lower red fluorescence and right anglelight side scatter (SSC) signals than Synechococcus. Eukaryotic phytoplankton had higher fluorescence and SSC signals than Synechococcus and were divided into 2 size-classes (small and large cells) tentatively identified as pico- and nanophytoplankton cells. The red fluorescence was used as a threshold parameter.
The settings (voltage of SSC and fluorescence photomultiplier tubes) were fixed and cell characteristics were normalized to fluorescent beads signals $(1.0 \mu \mathrm{m}$; Polysciences).

Nucleic acid extraction. Samples were extracted for community analysis using the autoclave DNA extraction method of Simmon et al. (2004). This consisted of crushing a frozen filter inside the microfuge tube, adding $0.5 \mathrm{ml} 1 \times \mathrm{TE}(10 \mathrm{mM}$ Tris$\mathrm{HCl}, \mathrm{pH} 7.5$; $1 \mathrm{mM}$ EDTA), vortexing to loosen cells bound to filter pieces, and autoclaving in a pre-heated chamber (AMSCO 3024-S isothermal sterilizer) under the following conditions: $10 \mathrm{~s}$ purge, sterilization at $121^{\circ} \mathrm{C}$ for $1 \mathrm{~min}$ and fast exhaust. The lysate was removed and placed onto a Centricon YM-100 spin column (Millipore) to concentrate and purify the DNA. The column was spun in a refrigerated centrifuge at $2630 \mathrm{rpm}(1500 \times \mathrm{g})$ for $20 \mathrm{~min}$. The column was subsequently washed twice with $0.75 \mathrm{ml} 1 \times \mathrm{TE}$ and spun for $30 \mathrm{~min}$. Columns were inverted and purified DNA was collected.

PCR amplification of 16S rDNA. Purified DNA samples were quantified using a GeneQuant pro (Amersham Biosciences) spectrophotometer. Ten to $100 \mathrm{ng}$ of DNA were used per $50 \mu \mathrm{l}$ PCR reaction. Genes encoding for 16S rRNA were amplified for T-RFLP analysis with the universal eubacterial fluorescently labeled (6-carboxyfluorescein [6-FAM]) forward primer 27F-(5'-6-FAMAGAGTTTGATC(A/C)TGGCTCAG-3') and the reverse primer 1492R (5'-GG(C/T)TACCTTGTTACGACTT$3^{\prime}$ ), producing an amplicon of $\sim 1500 \mathrm{bp}$ (Lane 1991).

PCR was performed in triplicate for each sample with the following final reagent concentrations in $50 \mu \mathrm{l}: 0.2 \mu \mathrm{M}$ each primer, $0.2 \mathrm{mM}$ each TaKaRa $E_{X}$ Taq dNTPs (Takara Bio), 1× Ex Taq buffer (2 mM $\mathrm{Mg}^{2+}$ ), $0.2 \mathrm{mg} \mathrm{ml}^{-1}$ BSA (10 $\mathrm{mg} \mathrm{ml}^{-1}$; Promega), $1.25 \mathrm{U}$ $\mu^{-1}$ Ex Taq polymerase, 10 to $100 \mathrm{ng}$ DNA template and brought to a final volume of $50 \mu \mathrm{l}$ with sterile diethylpyrocarbonate (DEPC)-treated water (Fisher Scientific). PCR amplification was performed under the following thermal conditions: initial denaturation at $95^{\circ} \mathrm{C}$ for $1.5 \mathrm{~min}, 30$ cycles at $95^{\circ} \mathrm{C}$ for $30 \mathrm{~s}, 50^{\circ} \mathrm{C}$ for $1 \mathrm{~min}, 72^{\circ} \mathrm{C}$ for $1.5 \mathrm{~min}$, and a final extension at $72^{\circ} \mathrm{C}$ for $7 \mathrm{~min}$ with a hold at $4^{\circ} \mathrm{C}$.

PCR products used for T-RFLP analysis were purified from a $0.8 \%$ agarose gel run in $1 \times$ TAE buffer with $0.05 \mu \mathrm{g} \mathrm{ml} \mathrm{m}^{-1}$ ethidium bromide. PCR products were isolated from the gel and purified with the QIAprep spin kit (QIAGEN) according to the manufacturer's instructions. Of each purified sample, $10 \mu \mathrm{l}$ were then digested with the restriction endonucleases CfoI and 
MspI (New England Biolabs) in separate $40 \mu \mathrm{l}$ reactions at $37^{\circ} \mathrm{C}$ for $4 \mathrm{~h}$. Digested DNA was precipitated for $1 \mathrm{~h}$ at $-20^{\circ} \mathrm{C}$ with 0.1 volumes $3 \mathrm{M} \mathrm{NaOAc}(\mathrm{pH} 5.2$ ) and $2.5 \times$ volume of cold $95 \%$ ethanol (molecular biology grade). DNA was pelleted at $13000 \mathrm{rpm}(9500 \times g)$ at $4^{\circ} \mathrm{C}$ for $1 \mathrm{~h}$. The DNA pellet was desalted with $70 \%$ ethanol, air-dried and re-suspended in $20 \mu \mathrm{l}$ sterile DEPC-treated water.

PCR amplification of 18S rDNA. Purified and quantified DNA samples were amplified for analysis by TRFLP of the 18S rRNA gene using the fluorescently labeled forward primer (6-FAM)-EUK-A (5'-6-FAMAACCTGGTTGATCCTGCCAGT-3') and the reverse primer EUK-570R (5'-GCTATTGGAGCTGGAATTAC$3^{\prime}$ ), which yielded an amplicon of $\sim 600 \mathrm{bp}$ (Countway et al. 2005). PCR was performed in triplicate for each sample, with the following final reagent concentrations in $50 \mu \mathrm{l}: 0.5 \mu \mathrm{M}$ each primer, $0.2 \mathrm{mM}$ each TaKaRa $E x$ Taq dNTPs, $1 \times E_{X}$ Taq buffer $\left(2 \mathrm{mM} \mathrm{Mg}^{2+}\right), 0.2 \mathrm{mg} \mathrm{ml}^{-1}$

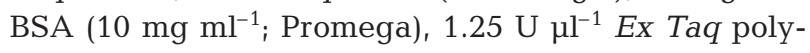
merase, 10 to $100 \mathrm{ng}$ template DNA and brought to a final volume of $50 \mu \mathrm{l}$ with sterile DEPC-treated water.

PCR amplification was performed under the following thermal conditions: initial denaturation at $95^{\circ} \mathrm{C}$ for $2 \mathrm{~min}, 35$ cycles at $95^{\circ} \mathrm{C}$ for $30 \mathrm{~s}, 55^{\circ} \mathrm{C}$ for $30 \mathrm{~s}, 72^{\circ} \mathrm{C}$ for $1 \mathrm{~min}$, and a final extension at $72^{\circ} \mathrm{C}$ for $5 \mathrm{~min}$ with a hold at $4^{\circ} \mathrm{C}$. Triplicate PCR products were pooled then cleaned and concentrated using the UltraClean PCR Clean-up Kit (Mo Bio Labs) according to the manufacturer's protocol. Concentrated PCR products ( 1000 ng) were digested with 5 U mung bean nuclease (New England Biolabs) to eliminate the effect of pseudo-terminal restriction fragments (T-RFs) on the T-RFLP analysis (Egert \& Frederich 2003). Mung bean digested PCR products were again purified and concentrated using the UltraClean PCR Clean-up Kit. Concentrated PCR products $(50 \mu \mathrm{l})$ were gel purified from a $0.8 \%$ agarose gel run in $1 \times$ TAE buffer with $0.05 \mu \mathrm{g} \mathrm{ml} \mathrm{m}^{-1}$ ethidium bromide using the UltraClean 15 DNA Purification Kit (Mo Bio Labs; Countway et al. 2005). Of each sample, $5 \mu$ l were digested in a total volume of $20 \mu \mathrm{l}$ with the restriction endonucleases $\mathrm{CfoI}$ and $\mathrm{MspI}$ in separate reactions at $37^{\circ} \mathrm{C}$ for $4 \mathrm{~h}$. Digested DNA was precipitated as described above for 16S rDNA samples and re-suspended in $10 \mu \mathrm{l}$ sterile DEPC-treated water.

T-RFLP analysis. Digested DNA (0.25 to $3 \mu \mathrm{l})$ was combined with 0.25 to $0.75 \mu \mathrm{l}$ of DNA standard (MapMarker 1000, Bioventures) and denatured after the addition of 2 volumes of deionized formamide at $95^{\circ} \mathrm{C}$ for $5 \mathrm{~min}$. Fragments were separated on an automated DNA sequencer (3100 Avant genetic analyzer, Applied Biosystems) in GeneScan mode $\left(15 \mathrm{kV}, 60^{\circ} \mathrm{C}\right.$ for $\left.40 \mathrm{~min}\right)$ using a $36 \mathrm{~cm}$ capillary and performance optimized polymer 4 (POP 4, Applied Biosystems). Fluorescence intensities of major peaks from community profiles were adjusted by increasing or decreasing template volumes and/or injection times to fall within 6500 to 8000 fluorescence units to ensure the comparability of profiles. The sizes of the 5'-T-RFs and corresponding fluorescence intensities (peak areas) were calculated using DAx ${ }^{\circledR}$ software (Data Acquisition and Analysis v7.0). A 150 fluorescence unit threshold value was used to separate true signals from background noise.

The richness of each community was estimated from the number of unique T-RFs in each restriction. In order to compare T-RFLP profiles, T-RFs from each community were binned according to fragment length ( $\pm 1 \mathrm{bp}$ ). Relative abundance was estimated for each T-RF by dividing the peak area by the total peak area and multiplying by 100 .

Resultant richness and abundance data were analyzed for comparison of communities. Similarity dendrograms were constructed using Primer $5^{\odot}$ software (Primer-E) applying the Bray-Curtis coefficient onT-RF relative peak abundances (log transformed) with the complete linkage similarity coefficient. SIMPER analysis (Primer $5^{\odot}$ software) of microbial community T-RFLP profiles was used to compare similarities within assemblages, dissimilarities between assemblages and to identify individual T-RFs responsible for clustered assemblages.

\section{RESULTS}

\section{Surface water temperature, chemistry, chlorophyll concentrations and bacterial abundance}

Surface water temperatures were $\sim 10^{\circ} \mathrm{C}$ in the northern Pacific, peaking between $35^{\circ} \mathrm{N}$ and $22^{\circ} \mathrm{S}$ to $27^{\circ} \mathrm{C}$ and decreasing to $-0.3^{\circ} \mathrm{C}$ in the southern part of the ocean (Fig. 2A). A peak in nitrate concentrations was observed in the sub-Arctic/Arctic Pacific HNLC (High Nutrient Low Chlorophyll) Zone, where iron limitation results in the accumulation of unutilized nitrate (Chisholm \& Morel 1991). A peak was also seen at the Equatorial Upwelling and the New Zealand Continental Shelf, where the spring bloom was underway (Fig. 2A). Chlorophyll concentration was greatest at $54^{\circ} \mathrm{N}\left(5.09 \mu \mathrm{g} \mathrm{l}^{-1}\right)$, with average values in the northern Pacific of $\sim 2.42 \mu \mathrm{g} \mathrm{l}^{-1}$; a substantial decrease in concentration was observed in the mid- to lower latitudes $\left(\sim 0.51 \mathrm{\mu g} \mathrm{l}^{-1}\right)$, and maximum concentration of $4.29 \mu \mathrm{g}^{-1}$ was found in the southern waters at $40^{\circ} \mathrm{S}$ (Fig. 2B). Bacterial abundance and production rates also showed latitudinal patterns, exhibiting bacterial cell concentrations of $\sim 2.70 \times 10^{8}$ cells $\mathrm{l}^{-1}$ in the northern Pacific through $30^{\circ} \mathrm{N}$, a decline from $30^{\circ} \mathrm{N}$ through

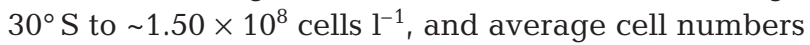



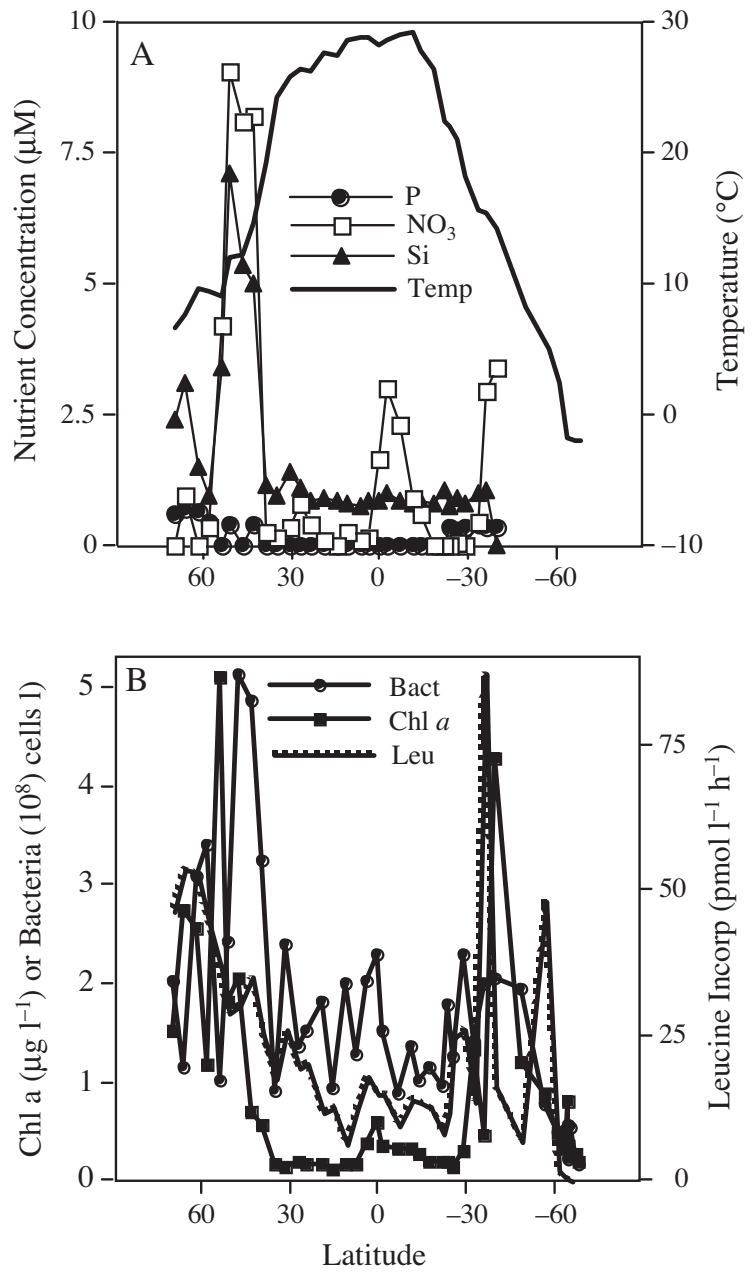

Fig. 2. Latitudinal trends in (A) surface orthophosphorus (P), nitrate $\left(\mathrm{NO}_{3}\right)$, silica (Si) and temperature; and (B) bacterial abundance (Bact), surface chlorophyll concentration (Chl a), and bacterial ${ }^{3} \mathrm{H}$-leucine incorporation (Leu). Positive latitude values represent Northern Hemisphere locations and negative latitudes represent the Southern Hemisphere

of $\sim 1.10 \times 10^{8}$ cells $\mathrm{l}^{-1}$ throughout southern Pacific waters (Fig. 2B). Bacterial production in the northern Pacific was $\sim 39.40$ pmol leucine (Leu) $\mathrm{l}^{-1} \mathrm{~h}^{-1}$, decreased to $\sim 14.50$ pmol Leu $\mathrm{l}^{-1} \mathrm{~h}^{-1}$ in the mid- to lower latitudes and peaked at $36^{\circ} \mathrm{S}$ with $87.50 \mathrm{pmol}$ Leu $\mathrm{l}^{-1} \mathrm{~h}^{-1}$ in the southern waters (Fig. 2B).

\section{Flow cytometry}

Flow cytometry analysis revealed the presence of Prochlorococcus between $35^{\circ} \mathrm{N}$ and $35^{\circ} \mathrm{S}$ (average abundance of $\sim 4.38 \times 10^{7}$ cells $\mathrm{l}^{-1}$ ) with a maximum

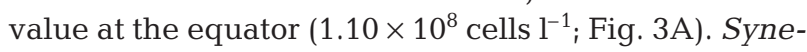
chococcus were present throughout the transect, with

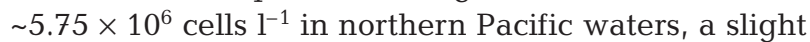
increase in average abundance throughout the mid- to
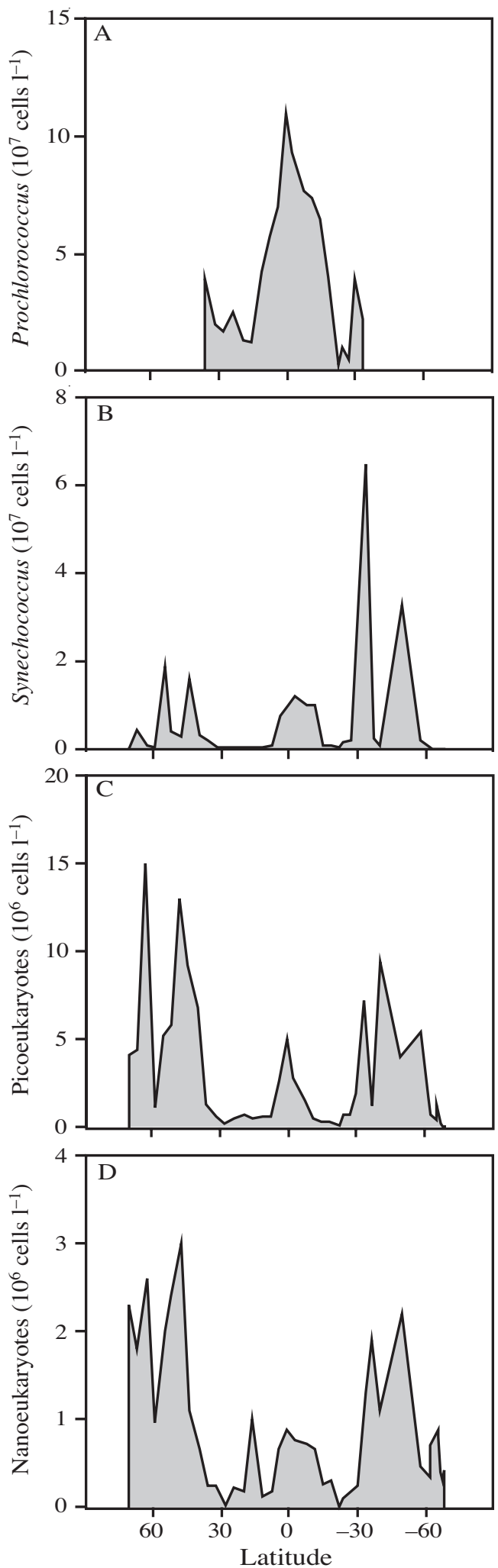

Fig. 3. Flow cytometric abundances of (A) Prochlorococcus, (B) Synechococcus, (C) picoeukaryotes and (D) nanoeukaryotes. Positive latitude values represent Northern Hemisphere locations and negative latitudes represent the Southern Hemisphere 
lower latitudes $\left(\sim 7.60 \times 10^{6}\right.$ cells $\left.\mathrm{l}^{-1}\right)$, and a peak in abundance at $33^{\circ} \mathrm{S}\left(\sim 6.50 \times 10^{7}\right.$ cells $\mathrm{l}^{-1}$; Fig. 3B). Photosynthetic picoeukaryote abundance followed latitudinal patterns as would be expected, with average abundance in the northern Pacific waters of $\sim 7.18 \times 10^{6}$ cells $1^{-1}$, decreased abundance in the mid- to lower latitudes $\left(\sim 1.47 \times 10^{6}\right.$ cells $\left.\mathrm{l}^{-1}\right)$ and a slight elevation at $30^{\circ} \mathrm{S}$ of $\sim 2.42 \times 10^{6}$ cells $^{-1}$ throughout the southern polar waters (Fig. 3C). Photosynthetic nanoeukaryote abundance also followed latitudinal trends with abundances in the northern Pacific and temperate/tropical regions of the Pacific of $\sim 2.11 \times 10^{6}$ and $\sim 3.38 \times 10^{5}$ cells $\mathrm{l}^{-1}$, respectively and $\sim 7.44 \times 10^{6}$ cells $\mathrm{l}^{-1}$ south from $30^{\circ}$ (Fig. 3D).

\section{Microbial community structure analysis: restriction endonuclease production of 5 '-terminal restriction fragments}

Prokaryotic and eukaryotic 5' T-RFLP profiles were generated following separate digestions of PCR products from each location with the endonucleases $\mathrm{CfoI}$ and MspI. The number of T-RFs from each sample obtained through MspI restriction of amplified 16S rDNA was greater than that determined with $C f o I$ generated fragments, with 8 to 38 and 4 to 20 T-RFs, respectively. PCR amplified $18 \mathrm{~S}$ samples restricted with $C f o I$ and MspI produced similar T-RF quantities of 5 to 23 and 6 to 25 T-RFs, respectively.

\section{Ribotype richness}

No latitudinal pattern of ribotype richness or community diversity between or amongst prokaryotic and eukaryotic profiles was found; however, the prokaryotic population appeared to have a higher ribotype richness with 181 total T-RFs produced, while eukaryotic populations produced 135 total T-RFs along the transect (data not shown). It is possible that this greater ribotype richness of the prokaryotic population is due to the lack of nuclease digestion prior to the T-RFLP analysis.

\section{Cluster analysis of T-RFLP profiles}

To assess similarity among prokaryotic and eukaryotic communities, T-RFLP patterns from each sampling location were implemented as a 'community fingerprint' based on the presence or absence of T-RFs and the relative amount of DNA for each T-RF. Communities analyzed through the use of hierarchical clustering of Bray-Curtis similarities indicated strong geographic integrity for 16S T-RFLP profiles but slightly less for the 18S profiles. Hierarchical analysis of 16S T-RFLP profiles indicated the presence of 4 distinct clusters sub-Arctic/Arctic (Group I), tropical (Group II), temperate (Group III) and sub-Antarctic/Antarctic (Group IV) - apportioned according to oceanic regions, suggesting a relationship with temperature and its environmental correlates (Fig. 4). According to SIMPER analysis, prokaryotic cluster groups contained high within-group average similarities ( 55 to $67 \%)$ and comparable inter-group similarity (average similarity 42 to $57 \%$ ). Groups I and II exhibited $44 \%$ similarity, Groups I and III $51 \%$ similarity, Groups I and IV, II and IV, and III and IV exhibited 47, 42 and $44 \%$ similarity, respectively, while Groups II and III had the highest degree of similarity at $57 \%$.

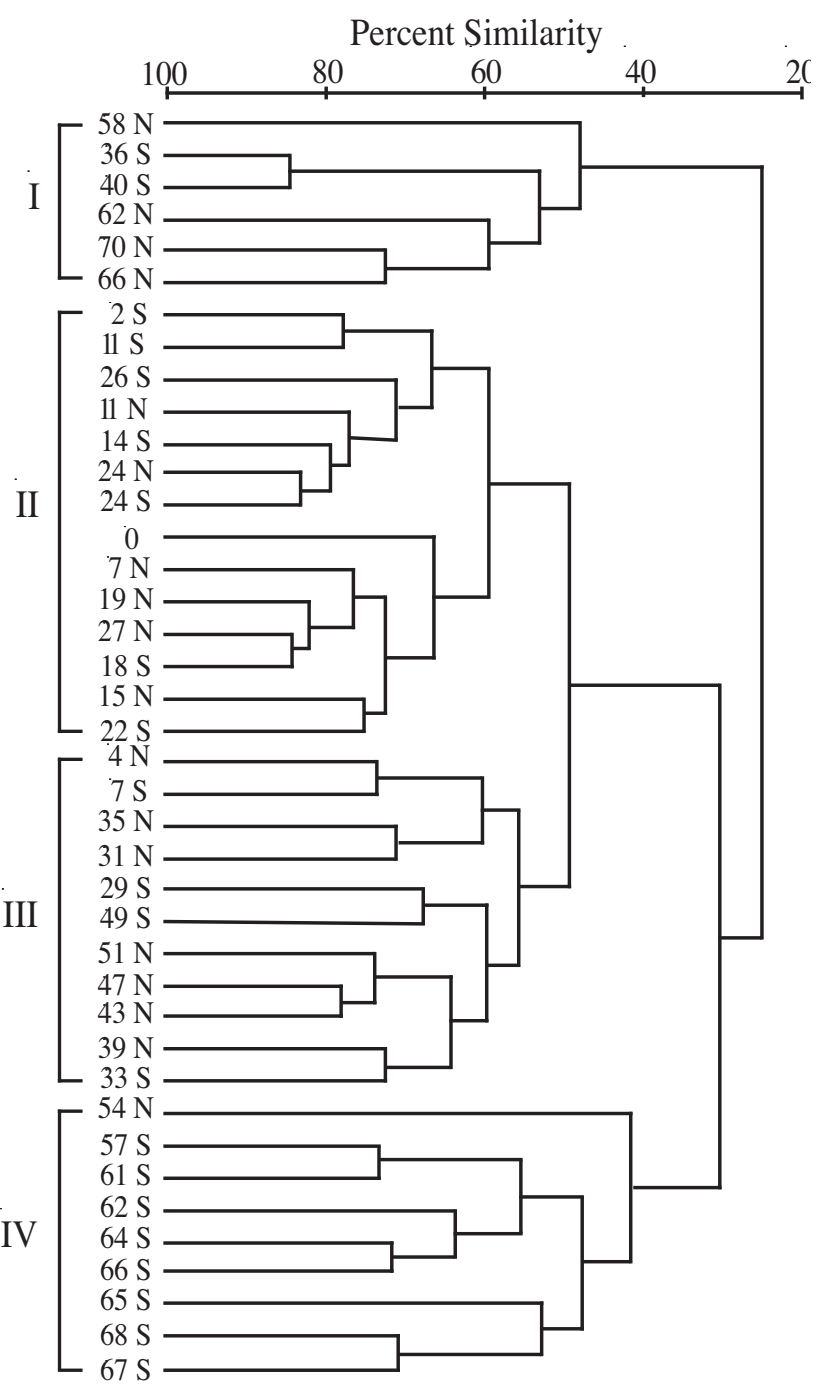

Fig. 4. 16S rDNA similarity dendrogram based on the presence/absence and relative abundances of CfoI and MspI restricted terminal restriction fragments (T-RFs) 
Hierarchical analysis of 18S T-RFLP profiles produced 4 major clusters following the same oceanic groupings as 16S profiles - sub-Arctic/Arctic (Group IV), tropical (Group II), temperate (Group I) and sub-Antarctic/ Antarctic (Group III) (Fig. 5), although the clusters were less congruent in their geographic constitution when compared to prokaryotic cluster assemblages. Eukaryotic assemblages had markedly high within-group average similarities ( 50 to $62 \%$ ), with Groups III and IV showing the highest inter-group similarity (average similarity $53 \%$ ) compared to all other inter-group assessments. Groups I and II, Groups I and III and Groups I and IV exhibited 48, 47 and 49\% similarity, respectively, while Groups II and IV and Groups II and III exhibited 49 and $48 \%$ similarity, respectively. Groups II and III had the highest degree of similarity at $53 \%$. Eukaryotic communities appeared to exhibit the same

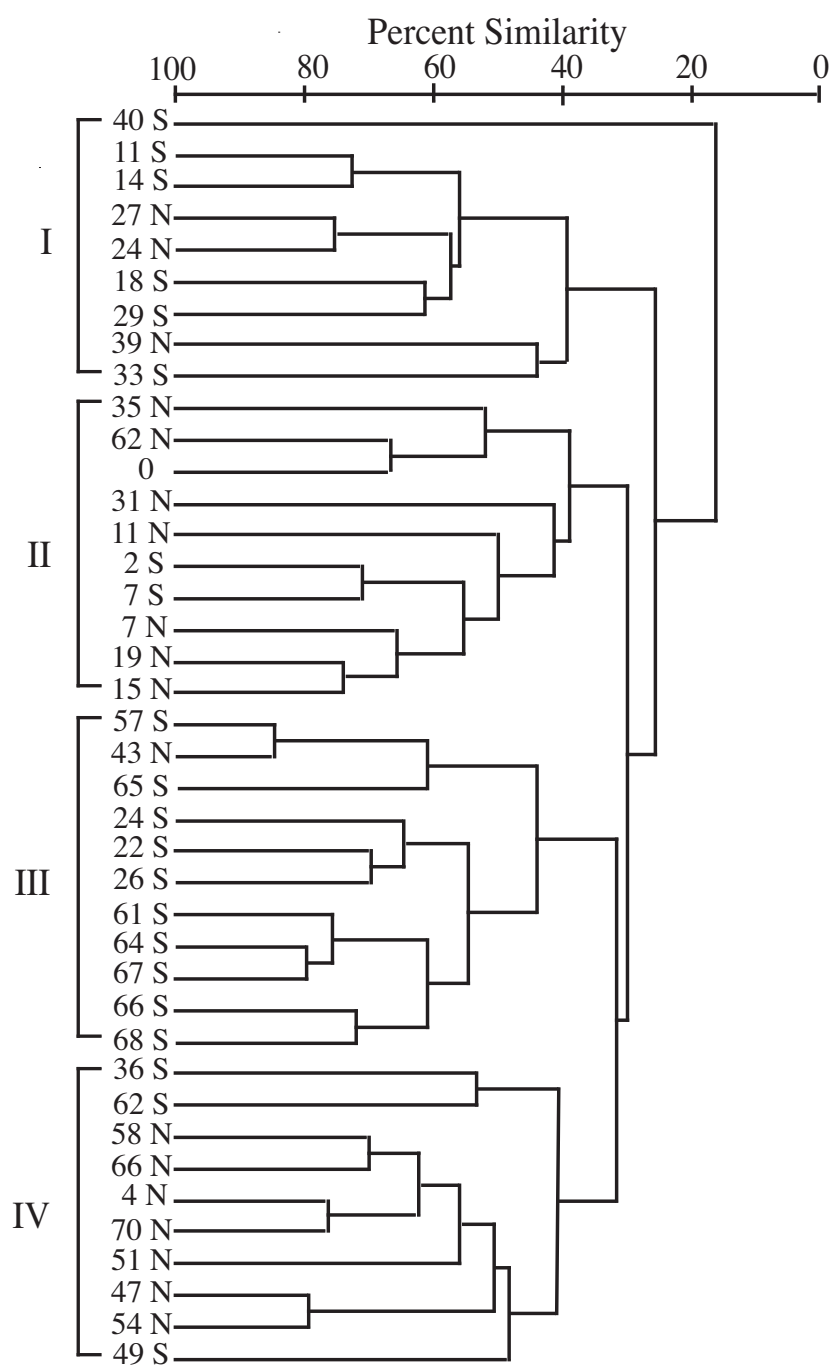

Fig. 5. 18S rDNA similarity dendrogram based on the presence/absence and relative abundances of CfoI and MspI restricted terminal restriction fragments (T-RFs) degree of within cluster similarity (51\%) over latitudinal gradients as the prokaryotic communities (52\%).

SIMPER analysis of profiles was used to determine the magnitude and identity of the T-RFs responsible for similarities within and dissimilarities between each group. Bacterioplankton community analysis revealed that 12 to 14 T-RFs were responsible for $>70 \%$ of each of the 4 cluster's within-group similarities, while eukaryotic community analysis revealed 8 to 11 T-RFs as the contributors to $>70 \%$ of the 4 cluster's withingroup similarities (Tables 1 \& 2). These results, coupled with the order-level resolution of the T-RFLP analysis, indicate that a small number of phylogenetic groups contributed to each distinct assemblage. In addition to being major contributors to within-group similarities, several of these T-RFs were present in most or all of the 16S T-RFLP profiles, suggesting a cosmopolitan distribution. The CfoI-derived 910 bp peak was consistently and substantially present in all profiles, contributing 26 to $92 \%$ of the total community $16 \mathrm{~S}$ rDNA and showing only lower relative abundance (10 to $35 \%$ of the total) in northern Pacific waters. CfoI-derived T-RFs 367, 564 and MspI-derived T-RFs 145 and 489 were also present at all latitudes, but contributed only 3 and $6 \%$ (367 and $564 \mathrm{bp}$ ) and 6 and $9 \%$ (145 and $489 \mathrm{bp}$ ) to the overall community structure (Table 1). Phylogenetic group(s) comprising the 489 bp peak showed high abundance (32\%) in Group II, while the phylogenetic group(s) representing the $145 \mathrm{bp}$ peak had an abundance of $25 \%$ in Group IV (Table 1).

Complementary patterns were observed in the eukaryotic samples along the transect. Eukaryotic phylogenetic groups representing fragments at 172 and 433 bp (CfoI-restricted) were present in all samples and contributed greatest to Group II (36 and 25\%) and least to Groups I and III (8 and 9\% for $172 \mathrm{bp}$ and $8 \%$ for $433 \mathrm{bp}$; Table 2). MspI-derived T-RFs 280 and 382 were also present in all samples, with T-RF 280 showing the greatest contribution to Group II (47\%) and the least to Groups I and III (8 and 9\%), and T-RF 382 showing an average contribution of $13 \%$ to all groups (Table 2). CfoI-restricted 419 and $426 \mathrm{bp}$ T-RFs were present throughout the transect profiles, although their respective abundances were typically low $(<3 \%)$. Of the T-RFs commonly present within eukaryotic community profiles, the MspI-derived 232, 240 bp T-RFs showed a considerable increase in abundance in sub-Antarctic/Antarctic T-RFLP profiles from sub-Arctic/Arctic and temperate/tropical profiles (1 to $4 \%$ ). As with prokaryotic profiles, several T-RFs varied in their presence and/or absence, with no apparent trends observed with respect to other T-RFs and/or latitude (data not shown).

Differences within prokaryotic clustering were primarily accounted for by T-RFs that were more 
Table 1. Mean relative abundance (Abund., average values as percentage) and percent contribution (Contrib., to the withingroup similarity) of $16 \mathrm{~S}$ rDNA 5 '-terminal restriction fragments (T-RFs) contributing to $>70 \%$ of within-group similarity. Average similarities: Group I $=58 \%$; Group II $=67 \%$; Group III $=60 \%$; Group IV $=55 \%$

\begin{tabular}{|c|c|c|c|c|c|c|c|c|c|c|c|}
\hline \multirow{2}{*}{$\mathrm{T}-\mathrm{RF}(\mathrm{bp})$} & \multicolumn{2}{|c|}{ - Group I - } & \multicolumn{3}{|c|}{ Group II -} & \multicolumn{3}{|c|}{ Group III- } & \multicolumn{3}{|c|}{ Group IV } \\
\hline & Abund. & Contrib. & T-RF (bp) & Abund. & Contrib. & T-RF (bp) & Abund. & Contrib. & T-RF (bp) & Abund. & Contrib. \\
\hline 910 CfoI & 31 & 8 & 910 CfoI & 64 & 11 & 910 CfoI & 74 & 12 & 910 CfoI & 67 & 12 \\
\hline $90 \mathrm{CfoI}$ & 24 & 8 & 439 MspI & 35 & 9 & 439 MspI & 25 & 9 & 145 MspI & 25 & 9 \\
\hline 93 CfoI & 14 & 7 & 489 MspI & 32 & 9 & $145 \mathrm{MspI}$ & 24 & 9 & 489 MspI & 10 & 7 \\
\hline $145 \mathrm{MspI}$ & 12 & 6 & $178 \mathrm{CfoI}$ & 11 & 7 & 489 MspI & 17 & 8 & $367 \mathrm{CfoI}$ & 5 & 6 \\
\hline 55 CfoI & 12 & 6 & $668 \mathrm{CfoI}$ & 16 & 6 & 367 CfoI & 6 & 6 & $439 \mathrm{MspI}$ & 6 & 5 \\
\hline $367 \mathrm{CfoI}$ & 7 & 6 & $145 \mathrm{MspI}$ & 8 & 6 & $137 \mathrm{MspI}$ & 3 & 5 & $518 \mathrm{CfoI}$ & 10 & 5 \\
\hline 489 MspI & 11 & 5 & 367 CfoI & 4 & 5 & $542 \mathrm{MspI}$ & 5 & 4 & 495 MspI & 11 & 4 \\
\hline 96 CfoI & 4 & 5 & $450 \mathrm{MspI}$ & 3 & 4 & 178 CfoI & 4 & 4 & 306 MspI & 6 & 4 \\
\hline 542 MspI & 3 & 4 & 435 MspI & 2 & 4 & $90 \mathrm{CfoI}$ & 2 & 4 & 93 CfoI & 4 & 4 \\
\hline 137 MspI & 2 & 4 & 137 MspI & 2 & 4 & $88 \mathrm{MspI}$ & 3 & 4 & $55 \mathrm{CfoI}$ & 1 & 4 \\
\hline $88 \mathrm{MspI}$ & 6 & 4 & 167 MspI & 1 & 4 & $450 \mathrm{MspI}$ & 2 & 4 & 497 MspI & 10 & 4 \\
\hline 487 MspI & 3 & 3 & 474 MspI & 2 & 3 & $474 \mathrm{MspI}$ & 4 & 3 & 564 CfoI & 1 & 3 \\
\hline 85 MspI & 6 & 3 & & & & & & & 85 MspI & 1 & 3 \\
\hline 437 MspI & 18 & 3 & & & & & & & 542 MspI & 2 & 3 \\
\hline
\end{tabular}

Table 2. Mean relative abundance (Abund., average values as percentage) and percent contribution (Contrib., to the withingroup similarity) of $18 \mathrm{~S}$ rDNA 5 '-terminal restriction fragments (T-RFs) contributing to $>70 \%$ of within-group similarity. Average similarities: Group I = 50\%; Group II = 54\%; Group III = 62\%; Group IV = 56\%

\begin{tabular}{|c|c|c|c|c|c|c|c|c|c|c|c|}
\hline \multicolumn{3}{|c|}{$\longrightarrow$ Group I } & \multicolumn{3}{|c|}{ Group II } & \multicolumn{3}{|c|}{ Group III } & \multicolumn{3}{|c|}{ Group IV } \\
\hline T-RF (bp) & Abund. & Contrib. & T-RF (bp) & Abund. & Contrib. & T-RF (bp) & Abund. & Contrib. & $\mathrm{T}-\mathrm{RF}(\mathrm{bp})$ & Abund. & Contrib. \\
\hline $382 \mathrm{MspI}$ & 29 & 13 & $382 \mathrm{MspI}$ & 39 & 12 & $382 \mathrm{MspI}$ & 74 & 12 & $172 \mathrm{CfoI}$ & 16 & 12 \\
\hline $196 \mathrm{CfoI}$ & 13 & 11 & $433 \mathrm{CfoI}$ & 41 & 25 & $172 \mathrm{CfoI}$ & 25 & 9 & 382 MspI & 18 & 11 \\
\hline $172 \mathrm{CfoI}$ & 8 & 8 & $172 \mathrm{CfoI}$ & 30 & 36 & $280 \mathrm{MspI}$ & 24 & 9 & $433 \mathrm{CfoI}$ & 14 & 11 \\
\hline $280 \mathrm{MspI}$ & 8 & 8 & $280 \mathrm{MspI}$ & 13 & 47 & $433 \mathrm{CfoI}$ & 17 & 8 & $280 \mathrm{MspI}$ & 12 & 11 \\
\hline 433 CfoI & 7 & 8 & 223 MspI & 5 & 54 & $368 \mathrm{MspI}$ & 6 & 6 & $596 \mathrm{CfoI}$ & 8 & 7 \\
\hline $598 M s p I$ & 2 & 5 & $426 \mathrm{CfoI}$ & 2 & 61 & 419 CfoI & 3 & 5 & 419 CfoI & 3 & 6 \\
\hline 600 CfoI & 2 & 5 & $378 \mathrm{MspI}$ & 8 & 66 & $232 \mathrm{MspI}$ & 5 & 4 & 279 CfoI & 2 & 6 \\
\hline 267 CfoI & 1 & 4 & 199 CfoI & 6 & 71 & 598 MspI & 4 & 4 & $196 \mathrm{CfoI}$ & 7 & 5 \\
\hline $286 \mathrm{MspI}$ & 3 & 4 & & & & 373 MspI & 2 & 4 & 223 MspI & 1 & 4 \\
\hline 430 CfoI & 1 & 4 & & & & & & & & & \\
\hline 279 CfoI & 1 & 3 & & & & & & & & & \\
\hline
\end{tabular}

dominant at the lower latitudes (e.g. MspI-derived $439 \mathrm{bp}$ peak) and those T-RFs that were dominant in sub-Arctic/Arctic regions, such as the Cfol-derived 55, 90, and $93 \mathrm{bp} \mathrm{T-RFs} \mathrm{and} \mathrm{the} \mathrm{MspI-derived} \mathrm{85,} 88$ and $437 \mathrm{bp}$ T-RFs (Table 1), where CfoI peaks 55, 90 and 93 showed an inverse relationship in abundance with the universally distributed 910 peak (data not shown). Several T-RFs were found solely in samples from specific biomes of the Pacific. CfoI-derived T-RFs 511 and 668, and MspI-derived 312 and 507 T-RFs, were either present at low frequencies or absent in high latitudinal zones, more abundant in the mid-latitudinal and equatorial waters and absent from subAntarctic/Antarctic waters (Fig. 6A). CfoI-derived TRFs 365, 518, 575 and 585 and MspI-derived T-RFs 92 and 540 were present only in samples from the subArctic/Arctic and/or sub-Antarctic/Antarctic (Fig. 6A).
Distinction between the 'tropical' assemblage and all other latitudinal groupings (I, III and IV) was ascribed mainly to the presence of the CfoI-derived $668 \mathrm{bp}$ peak. Using the Restriction Mapper program (Version 3; www.restrictionmapper.org) representatives of the Prochlorococcus clade produced terminal fragment lengths of 641 to 648 when digested with $C$ foI. This may offer a putative identification of this T-RF as a representative of the Prochlorophytes, as this peak is seen only in the temperate/tropical regions and coincides with the appearance of Prochlorococcus ( 4.38 $\times$ $10^{7}$ cells $\mathrm{l}^{-1}$ ) as seen in our flow cytometry results (Fig. 3). Several less abundant T-RFs ( $57 \%$ of all T-RFs) were present sporadically and showed no observable trends with respect to latitude.

Similar patterns in eukaryotic T-RFLP profiles were apparent, although less latitudinally congruent than 


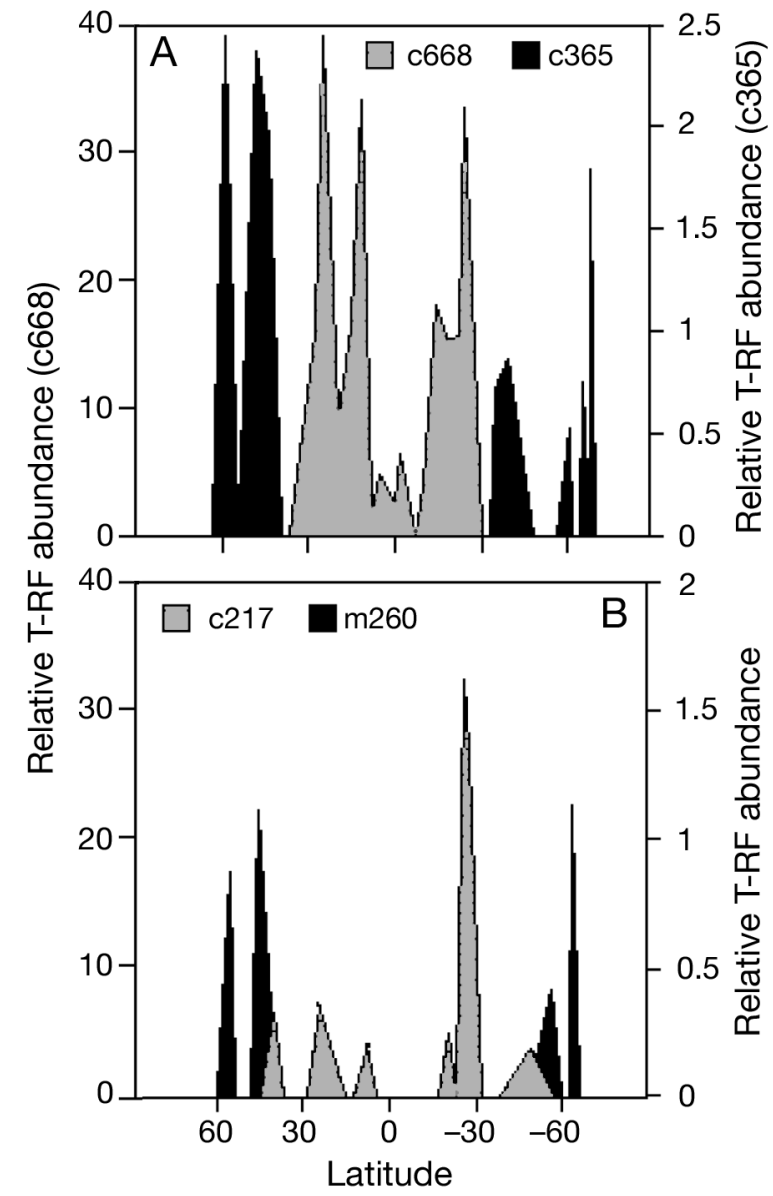

Fig. 6. Comparison of T-RFs representative of polar vs. tropi$\mathrm{cal} /$ temperate species of (A) prokaryotes and (B) eukaryotes. Other prokaryotic T-RFs CfoI 511, MspI 312 and 507 appeared only in temperate/tropical waters. Prokaryotic T-RFs CfoI 518, 575, 585, and MspI 92 and 540 appeared only in the polar latitudes. Eukaryotic T-RF CfoI 226 appeared only in the polar latitudes. Eukaryotic T-RFs CfoI 212, 285, 605 and MspI 114, 118, and 274 appeared in temperate/tropical waters (data not shown). Positive latitude values represent Northern Hemisphere locations and negative latitudes represent the Southern Hemisphere

prokaryotic profiles. The CfoI-derived 226 peak and the MspI-derived 260 peak appeared only in the polar latitudes (Fig. 6B), while CfoI-derived 212, 217, 285 and 605 T-RFs and MspI-derived 114, 118 and 274 TRFs appeared only in temperate/tropical regions (Fig. 6B). Several T-RFs (62\% of the total T-RFs generated) contributed only a small fraction to the total peak area of a community and appeared infrequently (<3 locations).

Overall, analysis of both the prokaryote and eukaryote profiles revealed several T-RFs that were present in all 4 biogeographic regions, although sometimes represented at only 1 latitude, lending the possibility that the phylogenetic groups representing these T-RFs are indeed globally distributed. Prokaryotic profiles showed that $25 \%$ of the T-RFs generated from both CfoI and MspI restrictions fall within this global distribution. Eukaryotic profiles showed that $16 \%$ of CfoIand MspI-generated T-RFs were globally distributed. In contrast, $8 \%$ of the prokaryotic T-RFs and $9 \%$ of the eukaryotic T-RFs constituted those groups found in only particular oceanic regions, suggesting a more endemic distribution.

\section{DISCUSSION}

Due to their small size, microorganisms are extremely abundant and disperse easily, leading some to believe that they are cosmopolitan in their distribution (Finlay 2002). Baas-Becking (1934) stated that 'everything is everywhere, and the environment selects', suggesting that local environmental conditions drive community composition. If we assume theories of cosmopolitanism to be true, then how do we explain the absence and/or presence of diverse species in the molecular analysis of microbial communities? Finlay (2002) suggests that some organisms may be extremely rare or present only in some cryptic form (e.g. cysts or spores) and hence not detected by broad detection methods (e.g. T-RFLP). In a comparison of microbial assemblages from the Arctic and Antarctic, Wilkinson (2001) proposed that universal distribution may be cell-size related, with ubiquitously distributed organisms maintaining an average size of $<100 \mu \mathrm{m}$, suggesting that overall global species richness is moderate.

A few studies have supported the hypothesis of universal distribution of microorganisms (Finlay \& Clarke 1999, Zwart et al. 2002), while others support the existence of endemic microorganisms (Whitaker et al. 2003). If microorganisms are truly endemic, our present day view of global microbial diversity and richness may be a gross underestimation. One way to determine the true distribution of microbial phylotypes is to use molecular-based methods to examine communities on large geographical scales. While by no means excluded from inherent biases (Suzuki \& Giovannoni 1996), PCRbased molecular techniques offer a fast and reliable approach to assessing diversity over these large spatial scales. Utilizing T-RFLP technology, we were able to assess the diversity of the dominant portions of microbial communities encompassing a range of the Pacific Ocean from the Arctic to the Antarctic circles. Microbial diversity studies have traditionally been limited to smaller spatial scales and isolated environments, making this study unique in its scope.

T-RFLP analysis of Pacific Ocean microbial communities indicated 4 major groupings (clusters) represen- 
tative of the sub-Arctic/Arctic Pacific, temperate Pacific, tropical Pacific and the sub-Antarctic/Antarctic Pacific Ocean. High within-group similarities for both prokaryotic and eukaryotic communities were driven by a relatively low number of T-RFs (8 to 14). This could be the result of several different phylogenetic clades sharing identical terminal restriction sites, resulting in the same length terminal fragment. Microbial community analysis revealed many phylogenetic groups that were ubiquitously distributed as well as those isolated to specific habitats in both prokaryotic and eukaryotic fractions. For our purposes, a ubiquitous ribotype (T-RF) is one appearing in all 4 regions of the Pacific Ocean, while an endemic ribotype is seen only in specific habitat types (e.g. the polar regions or the temperate/tropical regions). We did not observe prokaryotic populations restricted solely to the subArctic/Arctic or sub-Antarctic/Antarctic, but rather populations existing in both polar regions. It has been suggested by Hollibaugh (1994) that there may be phylogenetic differences between bacterioplankton communities in response to varying types of organic matter present in the local environment due to the requirement for specialized metabolic capabilities in utilizing local substrates. It is possible that organisms may be ubiquitously dispersed throughout the Pacific, but in a non-functioning state awaiting local conditions to become favorable. In comparison to our findings of Pacific Arctic bacterioplankton communities, Ferrari \& Hollibaugh (1999) analyzed samples from the Canadian Arctic using DGGE and identified 5 major clusters with similarities greater than $80 \%$. Their findings suggested that bacterioplankton communities in this area of the Arctic are the result of responses to local environmental conditions.

Several populations of microbes were found to be restricted to the temperate and tropical latitudes, possibly in response to higher temperatures and lower nutrient resources, although we did observe a peak in nitrate at the Equatorial Upwelling zone, where we also saw an increase in eukaryotic phytoplankton (pico- and nano-), Prochlorococcus, and Synechococcus from the immediate northern waters. Distinctions between the temperate and tropical assemblages and the polar assemblages resulted from the presence of a few peaks. Prokaryotic communities were dominated by $\sim 4$ T-RFs in these regions, with the most dominant T-RF being the CfoI-derived 668 bp peak. The appearance of this T-RF coincided with flow cytometry determined Prochlorococcus abundances observed at the temperate/tropical latitudes. Campbell et al. (1994) observed the ubiquity of Prochlorococcus in the latitudinal band from $40^{\circ} \mathrm{N}$ to $40^{\circ} \mathrm{S}$ in the central Pacific Ocean, where they showed that it comprises a significant portion of the photosynthetic biomass. Synecho- coccus was represented in all regions of the Pacific Ocean as shown by flow cytometry analysis. These cyanobacterial groups are an important food source for planktonic heterotrophic flagellates and ciliates (Yahel et al. 1998) and greatly contribute to the total primary production in tropical regions (Li et al. 1983). We are unable to say absolutely that the CfoI-derived $668 \mathrm{bp}$ T-RF is representative of Prochlorococcus given that T-RFLP does not allow complete identification of T-RFs, but based on preliminary computational restriction digestion with the Restriction Mapper program, we are able to relate this T-RF with Prochlorococcus. We were, however, unable to determine the T-RF that may be representative of Synechococcus. Eukaryotic mid- and lower latitude communities were dominated by $\sim 7$ T-RFs endemic to this region, of which the CfoIderived $285 \mathrm{bp}$ T-RF was the most dominant.

Prokaryotic communities showed high similarity across the transect, although not all communities shared the same members throughout. This similarity may be explained by the findings of earlier investigators in that most marine bacteria belong to only 9 phylogenetic groups (Giovannoni \& Rappé 2000). Eukaryotic communities also showed high similarity across the transect, but a decreased number of T-RFs were generated in comparison to prokaryotic populations. This may be due to the selection of primers used to amplify eukaryotic DNA from the mixed assemblage, under-sampling, the addition of a nuclease digestion step, or the fact that prokaryotic organisms are smaller and more abundant than eukaryotic organisms. We could hypothesize that the eukaryotic fraction contains fewer members than the prokaryotic fraction based on the ecological principle that the number of individuals in a community is inversely proportional to their size (Fenchel 1993). It is also possible that some of the prokaryotic T-RFs actually represent eukaryotic plastids. Rappé et al. $(1997,1998)$ reported significant numbers of eukaryotic plastids from 16S rRNA gene clone libraries off the Atlantic and Pacific coasts of the United States. It is therefore possible that the absence of pre-filtration in our samples resulted in some $16 \mathrm{~S}$ T-RFs representing eukaryotic plastids.

The selection of restriction enzyme(s) used for T-RFLP also has a substantial effect on the resolution of the microbial community and the phylogenetic groups detected. This is due to the possibility that different phylogenetic groups may have enzyme-specific terminal-end cut sites at the same location on the PCR amplicon, resulting in the same size terminal fragment. Our selection and analysis using 2 restriction enzymes offer higher resolution than a single enzyme; however, we are aware that some T-RFs may represent more than one phylogenetic group, resulting in an underestimation of the richness of Pacific Ocean 
microbial communities. Since the major goal of this study was to provide a broad spatial overview of microbial diversity in the Pacific Ocean, the use of different and/or more restriction enzymes would not necessarily increase the power of the analysis in contrast to the additional time and monetary expenditures required.

T-RFLP only recognizes the dominant members of a community, resulting in a somewhat skewed version of 'true' diversity. Low abundance members in a community may be overlooked by molecular-based methods due to sampling biases (Finlay 1998). Sampling size may influence the true diversity of a community by under-representing or excluding particular community members from small sampling sizes. Prokaryotic communities are probably less affected by our sample size (1 1) but eukaryotic organisms may require a larger sampling volume to include all representatives of the local community. Although another potential bias is the method used for DNA extraction, the protocol used was developed, in part, to improve DNA extraction from organisms which are difficult to lyse. It is assumed that our method is sufficiently robust to include all members of the microbial community (see Simmon et al. 2004), although we cannot eliminate the possibility that this method excludes the cryptic forms (e.g. spores) present as a 'seed bank', thus overlooking these phylogenetic groups which may be ubiquitously present but dormant (Finlay 2002). Although we are aware of the potential biases in our analysis, their elimination is not yet possible and will continue to be a drawback to these types of molecular approaches and large geographical surveys.

The seasonal variability along this transect may also contribute to the observed segregation of both the prokaryotes and eukaryotes into the 4 distinct biogeographical regions, as sampling in the Northern Hemisphere was completed during the late summer and Southern Hemisphere sampling occurred during the Austral spring. The results represent a 'snap shot' of the microbial diversity along a $15400 \mathrm{~km}$ geographical region during a sampling time window that was as short as logistically possible.

The results herein represent a broad overview of microbial diversity on a geographic scale never before available. Discernable patterns are apparent and there is evidence that some phylotypes co-exist, while some increase in abundance only in the absence of other species. In order to obtain a more detailed view of the phylogenetic composition of these Pacific Ocean microbial communities, possibly link community structure to function, and present a more complete picture of ubiquity versus endemicism in the Pacific Ocean, cloning and sequencing must be employed, which was beyond the scope of this study.
Acknowledgements. We thank the captain, crew and Raytheon Polar Services personnel of the RVIB 'Nathaniel B. Palmer' for their service and assistance at sea, and R. Stevens for his assistance with sample collection. Nutrient analyses were provided by J. Macauley at the University of West Florida Wetlands Research Laboratory. We are grateful to the National Science Foundation Office of Polar Programs for their efforts to facilitate our participation in this ship of opportunity cruise. This research was supported by National Science Foundation award OPP 0127022 to W.H.J.

\section{LITERATURE CITED}

Baas-Becking LGM (1934) Geologie of inleidning tot de milievkunde. WP van Stokum \& Zoon NV, The Hague

Benson DA, Karsch-Mizrachi I, Lipman DJ, Ostell J, Wheeler DL (2004) GenBank: update. Nucleic Acids Res 32:D23-26

Campbell L, Nolla HA, Vaulot D (1994) The importance of Prochlorococcus to community structure in the central North Pacific Ocean. Limnol Oceanogr 39:954-961

Chisholm SW, Morel FMM (1991) What controls phytoplankton growth in nutrient-rich open areas of the open sea. Limnol Oceanogr 36:1507-1565

Countway PD, Gast RJ, Savai P, Caron DA (2005) Protistan diversity estimates based on 18S rDNA from seawater incubations in the Western North Atlantic. J Eukaryot Microbiol 52:1-12

Darling KF, Wade CM, Stewart IA, Kroon D, Dingle R, Brown AJL (2000) Molecular evidence for genetic mixing of Arctic and Antarctic subpolar populations of planktonic foraminifers. Nature 405:43-47

DeLong EF (1998) Archaeal means and extremes. Science 280:542-543

Diez B, Pedros-Alio C, Massana R (2001) Study of genetic diversity of eukaryotic picoplankton in different oceanic regions by small-subunit rRNA gene cloning and sequencing. Appl Environ Microbiol 67:2932-2941

Egert M, Friedrich MW (2003) Formation of pseudo-terminal restriction fragments, a PCR related bias affecting terminal restriction fragment length polymorphism analysis of microbial community structure. Appl Environ Microbiol 69:2555-2562

Fenchel T (1993) There are more small species than large species. Oikos 68:375-378

Ferrari VC, Hollibaugh JT (1999) Distribution of microbial assemblages in the Central Arctic Ocean Basin studied by PCR/DGGE: analysis of a large data set. Hydrobiologia 401:55-68

Finlay BJ (1998) The global diversity of Protozoa and other small species. Int J Parasitol 28:29-48

Finlay BJ (2002) Global dispersal of free-living microbial eukaryote species. Science 296:1061-1063

Finlay BJ, Clarke KJ (1999) Ubiquitous dispersal of microbial species. Nature 400:828

Fuhrman JF, McCallum K, Davis A (1993) Phylogenetic diversity of subsurface marine microbial communities from the Atlantic and Pacific Oceans. Appl Environ Microbiol 59: 1294-1302

Gast RJ, Dennett MR, Caron DA (2004) Characterization of protistan assemblages in the Ross Sea, Antarctica, by denaturing gradient gel electrophoresis. Appl Environ Microbiol 70:2028-2037

Giovannoni SJ, Rappé M (2000) Evolution, diversity, and molecular ecology of marine prokaryotes. In: Kirchman DL (ed) Microbial ecology of the oceans. Wiley-Liss, New York, p 47-84 
Giovannoni SJ, Britschgi TB, Moyer CL, Field KG (1990) Genetic diversity in Sargasso Sea bacterioplankton. Nature 345:60-63

Gomez ED, Garland JL, Roberts MS (2004) Microbial structural diversity estimated by dilution extinction of phenotypic traits and T-RFLP analysis along a land-use intensification gradient. FEMS Microbiol Ecol 49:253-259

Hollibaugh JT (1994) Relationship between thymidine metabolism, bacterioplankton community metabolic capabilities, and sources of organic matter. Microb Ecol 28: $117-131$

Lane DJ (1991) 16S/23S rRNA sequencing. In: Stackebrandt E, Goodfellow M (eds) Nucleic acid techniques in bacterial systematics. John Wiley \& Sons, New York, p 115-175

Li WKW, Subba Rao DV, Harrison WG, Smith JC, Cullen JJ, Irwin B, Platt T (1983) Autotrophic picoplankton in the tropical ocean. Science 219:292-295

Liu W, Marsh TL, Cheng H, Forney LJ (1997) Characterization of microbial diversity by determining terminal restriction fragment length polymorphisms of genes encoding 16S rRNA. Appl Environ Microbiol 63:4516-4522

Moon-van der Staay SY, De Wachter R, Vaulot D (2001) Oceanic 18S rDNA sequences from picoplankton reveal unsuspected eukaryotic diversity. Nature 409:607-610

Mummey DL, Stahl PD (2003) Spatial and temporal variability of bacterial 16S rDNA-based T-RFLP patterns derived from soil of two Wyoming grassland ecosystems. FEMS Microbiol Ecol 46:113-120

Norris RD, de Vargas C (2000) Evolution all at sea. Nature 405:23-24

Porter KG, Feig YS (1980) The use of DAPI for identifying and counting aquatic microflora. Limnol Oceanogr 25: 243-248

Rappé MS, Kemp PF, Giovannoni SJ (1997) Phylogenetic diversity of marine coastal picoplankton 16S rRNA genes cloned from the continental shelf off Cape Hatteras, North Carolina. Limnol Oceanogr 42:811-826

Rappé MS, Suzuki MT, Vergin KL, Giovannoni SJ (1998) Phylogenetic diversity of ultraplankton plastid smallsubunit rRNA genes recovered in environmental nucleic

Editorial responsibility: John Dolan, Villefranche-sur-Mer, France acid samples from the Pacific and Atlantic coasts of the United States. Appl Environ Microbiol 64:294-303

Simmon K, Steadman D, Durkin S, Baldwin A, Jeffrey WH, Sheridan P, Horton R, Shields MS (2004) An autoclave method for rapid preparation of bacterial PCR template DNA. J Microbiol Methods 56:143-149

Smith DC, Azam F (1992) A simple, economical method for measuring bacterial protein synthesis rates in seawater using ${ }^{3} \mathrm{H}$-leucine. Mar Microb Food Webs 6:107-114

Suzuki MJ, Giovannoni SJ (1996) Bias caused by template annealing in the amplification of mixtures of $16 \mathrm{~S}$ rRNA genes by PCR. Appl Environ Microbiol 62:625-630

Urakawa H, Yoshida T, Nishimura M, Ohwada K (2001) Characterization of microbial communities in marine surface sediments by terminal-restriction fragment length polymorphism (T-RFLP) analysis and quinone profiling. Mar Ecol Prog Ser 220:47-57

US EPA (Environmental Protection Agency) (1983) Methods for chemical analysis of water and wastes. Document EPA/600/4-79/020, US EPA Office of Research and Development, Washington, DC

Ward DM, Weller R, Bateson MM (1990) 16S rRNA sequences reveal uncultured inhabitants of a well-studied thermal community. FEMS Microbiol Lett 75:105-115

Welschmeyer NA (1994) Fluorometric analysis of chlorophyll $a$ in the presence of chlorophyll $b$ and pheopigments. Limnol Oceanogr 35:1985-1992

Whitaker RJ, Grogan DW, Taylor JW (2003) Geographic barriers isolate endemic populations of hyperthermophilic archaea. Science 301:976-978

Wilkinson DM (2001) What is the upper size limit for cosmopolitan distribution in free-living microorganisms? J Biogeogr 28:285-291

Yahel G, Post AF, Fabricius K, Marie D, Vaulot D, Genin A (1998) Phytoplankton distribution and grazing near coral reefs. Limnol Oceanogr 43:551-563

Zwart G, Crump BC, Agterveld M, Hagen F, Han SK (2002) Typical freshwater bacteria: an analysis of available $16 \mathrm{~S}$ rRNA gene sequences from plankton of lakes and rivers. Aquat Microb Ecol 141-155

Submitted: August 11, 2005; Accepted: October 6, 2005 Proofs received from author(s): November 4, 2005 